\title{
How Well Does Botswana's Social Studies Curriculum Articulate Gender Issues? A Preliminary Overview
}

\author{
Keene Boikhutso ${ }^{1, *}$ \\ ${ }^{1}$ Department of Languages and Social Sciences Education, Faculty of Education, University of Botswana, Gaborone, \\ Botswana \\ *Correspondence: Department of Languages and Social Sciences Education, Faculty of Education, University of \\ Botswana, Private Bag UB 702 Gaborone, Botswana Tel: 267-355-2374 E-mail: Boikhutso@mopipi.ub.bw
}

Received: November 19, 2012 Accepted: December 11, $2012 \quad$ Online Published: January 16, 2013

doi:10.5430/jct.v2n1p54

URL: http://dx.doi.org/10.5430/jct.v2n1p54

\begin{abstract}
In this paper I discuss the extent to Botswana's social studies curriculum is gendered thus more likely to reproduce gender inequalities. The paper locates gender issues within the broader context of male-dominated patriarchal society. It applies content analysis to establish whether or not the Social Studies syllabuses articulate gender issues. I argue that past curriculum reforms implemented in the backdrop of the recommendations of the 1977 first National Commission on Education and the 1994 Revised National Commission of Education have not led to the transformation of the social studies curriculum in terms of gender equality. It finds that past attempts aimed at integrating gender issues have been superficial hence unlikely to yield expected outcomes of benefitting women and men equally. It concludes by calling for the further review of the gendered social studies curriculum so as to enable it to provide equal opportunities for women and men.
\end{abstract}

Keywords: gender; mainstreaming; equality; inequality; social studies; curriculum; education; globalization

\section{Introduction}

The Botswana government just like other African countries has long realized the need to mainstream gender in all educational, political, economic and societal spheres. According to Arnot and Fennell (2008), this realization partly stems from the international agenda of Education For All and the Millennium Development Goal's call for gender equality in education by 2015. Even the 1995's United Nations Beijing Platform of Action challenged more specifically education researchers to design and implement education strategies that institutionalized gender equitable development (Nyati-Ramahobo, 1992; United Nations Organization, 1995; Mannathoko, 1999). A lot of focus has been in explaining gender difference, oppression and ensuring that boys and girls have equal access and opportunities to education (Nyati-Ramahobo 1992; Seboni 1997; Mannathoko 1995; 1999). However, Mannathoko (1999) and Arnot \& Fennell (2008) observe that deliberate effort to move beyond statistical category of boys and girls and look at the impact of national educational policies on gender relations and ways of mitigating these have been slow. In the past four decades the Botswana government has rightly recognized curriculum as a transformation tool in terms of realizing human rights and the development agenda. To this end government has committed itself towards the achievement of greater level of gender justice and human rights through the periodic review of the primary and secondary school curriculum. First, was the institution of the 1977 National Commission on Education commonly referred to as Education for Kagisano i.e. education for the promotion of social harmony and cohesion. Next was the implementation of the 1994 revised national policy on education whose main aim was to consolidate and reinforce earlier curricula reforms.

The Ministry of Education and Skills Development (MoESD) for example, sees the revised junior secondary school syllabus which was implemented in 2010 as marking the attainment of quality education, the ideals reflected in the Revised National Policy on Education and closer realization of the aspirations reflected in the national 2016 Vision (http://www.moe.gov.bw). Consistent with the neoliberal view of education is the perception that high quality education is a pre-requisite for increased productivity and competitiveness leading to a higher standard of living for 
all citizens. In other words, the Botswana government recognizes that globalization is characterized by the increasingly interdependent regional and global economy. Hence competiveness is central to the development of human resource with the necessary competencies particularly among young people (http://www.moe.gov.bw). To this end, the Botswana's Ten Year Social Studies programme has two phases. Learners in lower primary school, that is, standard 1 through to 4 do cultural studies and environmental science as core instead of social studies. However, learners in upper primary, that is, standard 5 through to 7 and junior secondary take social studies as a core. Learners taking Botswana General Certificate of Secondary Education (BGCSE) in forms 4 and 5 take social studies as an optional subject. UNESCO (2003) makes the persuasive assumption that education can make a major contribution to the promotion of gender equality in society. This paper therefore explores the question: how well does Botswana's primary, junior and senior secondary school social studies curriculum articulate gender issues?

\section{Gender Issues in/and School Curricula}

In order to appreciate the extent to which the Botswana social studies curriculum articulate gender issues, it is important to locate the debate in the context of the discourses relating to the gendered nature of the school curricula. The paper draws upon the insights of gender education theory to understand how the school curricula shape the attitudes, behaviours and perceptions of boys and girls in general. It also draws on liberal and more recent African feminist perspectives to understand the gendered nature of the school curricula (Stromquist 1990; Mannathoko 1999; Arnot \& Dillabough 2000; Nyamu 2000; Skelton Francis \& Smulyan 2006; Mama 2007; Fennell and Arnot 2009; Chilisa and Ntsabane 2010). Stromquist (1990) and Gordon (1996) disclose that the various feminist perspectives all recognize that states are not neutral institutions but are the key actors regulating and promoting educational processes and outcomes which have important implications for women's subordination and exploitation. Similarly, Arnot and Fennell (2008) remind us that:

the provision of schools, teachers and curriculum are concerns of the state. National education policy has regarded education as part of a single, uniform package to be offered to all citizens... The social reality of discrimination and exclusion that mar the educational experiences of the subordinated woman and man and that obstruct, even oppose, their entry into modern economy does not usually find a place in official documentation of provision of education in developing countries (p. 517).

However, Stromquist (1990) is quick to point out that such an analysis does not necessarily preclude and undermine the critical role played by other change agents and actors such as students, parents and civil society and in particular women-run organizations in their effort to promote gender equality.

In the early years of gender research in education especially in the 1970s and 1980s, sex-role theory was dominant. A lot of debate centred on issues around sex and gender, sex role socialization. It is only recently that focus has now shifted to questions about gender identity and social construction of gender (Deem 1980; Mannathoko 1999; Wolpe 1988; Arnot \& Dillabough 2000). Liberal feminist perspectives of schooling for example, emphasized the socializing role of education. Schools in particular, were seen to shape male and female behavior to conform to the prescribed gender roles as well as politically, culturally, situationally and socially constructed gender distinctions and perceptions (Friedman 1995; Connell 2000; Tripp 2000; Mama 2003). Marshall and Arnot (2007) argue that in most cases school knowledge is highly gendered thus plays a critical role in the formation, maintenance and sustenance of gender identities, hierarchies and inequalities within a society. Gordon (1996) stresses that African feminists have for example, explored the role of the state in using educational policy and practice to not only perpetuate and reproduce patriarchy but also facilitate the continued domination and exploitation of women both in the colonial and post-colonial period.

The relationship between the school curriculum and pedagogy generally reflect the structure of inequality in the larger society. That is to say that there is a real connection between schooling, economic, cultural and political power. Apple (1998) is of the opinion that the underlying reality can only be uncovered by "getting inside ...the school ...to see what actually happens and by examining the relationship between education and 'the state' and between culture and the economy" (p.8). This is not surprising given that the traditional curriculum is a political document. Tupper (2002) and Mirza (2004) suggest that the content of the curriculum is controlled by the state thus reflect the masculine canon of politics and economics. Gender stereotypes are not only reinforced through teachers' attitudes and expectations but also through textbooks which tend to have a strong male bias by depicting girls and women in stereotypical ways (Marira 1991; Gordon 1996; Mirza 2004). In the case of Botswana past studies, for example, Mannathoko (1999) has demonstrated that educational stereotyping contributes to the marginalization of women. In fact, gender stereotyping is still evident in subjects such as Social Studies, English, Science and Setswana. 
Thorne (1993) maintain that the 'hidden' school curriculum is also instrumental in shaping males' and females' perspectives of gender. However, this is a contested terrain as scholars like Eder and Parker (1987) suggest that boys and girls have different cultures in schools while others like Lewin and Sayed (2003) disprove this popular notion. For some scholars male and females tend to act out images of masculinity and feminity not only inside the classrooms and but also outside thus reinforcing the gendering of the 'hidden' school curriculum (Eder and Parker 1987; Lewin and Sayed 2003; www.ungei.org; www.ioe.ac.uk.efps/beyondaccess). Thorne (1993) for example disagrees but at the same time provides an alternative view by saying "as individuals... we always display or "do" gender, but this dichotomous difference may be more or less relevant, and relevant in different ways, from one social context to another' (p. 29).

\section{Gender in Social Studies Education}

Education generally is an inalienable human right thus the school provides an essential space and time for the formalization of learning, the construction of knowledge and manifestation of diversity and differences (Tetreault 1987; Cosme and De Deus 2003; Tupper 2002). Gender in social studies education is part of the school curriculum that seeks to develop concepts of 'ourselves' with and through 'other'. The main idea is to understand those who surround and define us that is, the 'world' (Tetreault 1987; Cosme and De Deus 2003; Tupper 2002). Unfortunately, social studies education is still premised on gender stereotypes rather than multicultural approaches. For example, social studies textbooks still represent female and male citizen identities in ways that promote the sustenance of prejudice and social discrimination. That is, the social studies content is generally not free from gender bias and discriminates against women and the girl child. This leads to the creation of gender boundaries which define masculine and feminine notions and qualities for men and women respectively (Tetreault 1987; Hurren 2002; Daatland 2003; Tupper 2002).

While the content as contained in social studies textbooks is an important aspect regarding gender balance in social studies education, the overall curriculum and structure of the subject area is also critical. In particular, the expanding horizon structure of social studies where learners are taken from the known to the unknown or the local to the global, has inherent problems. In the view of Hurren (2002), this structure requires that young learners, more often taught by women study topics such as self and the family. In contrast, older learners, more often taught by men expand the study to world issues, international relations and conflicts. Hurren (2002) further charges that this overarching structure of social studies education invariably supports a hierarchical framework that privilege public (i.e. global issues) over private (i.e. local issues) spheres of life. Interestingly, such a hierarchical framework also implies that the study of issues traditionally associated with men require a more sophisticated mature learner than the study of self, family and community issues traditionally associated with women.

\section{Botswana's Social Studies School Curriculum}

The development of social studies in Botswana needs to be understood in the context of the New Social Studies movement and the African Social Studies Programme (ASSP). Howe and Marshall (1999) observe that the New Social Studies movement in the United States gained currency in the 1950s and 1960s and emphasized social participation, citizenship empowerment and active student engagement. In the early 1970s there was the general discontent that Botswana's education system was not relevant to the needs of Batswana. Boikhutso (1993) suggests that the education system was seen as promoting colonial legacy hence there was need for a home grown school curriculum. The government acceded to public pressure and instituted a commission of inquiry in 1975 which produced the report entitled Education for Kagisano in 1977. This report among other things called for the introduction of social studies in the junior secondary school curriculum.

As a result of the commission, social studies was introduced into the primary and the junior school curriculum as a core subject in 1982. It replaced geography and history and other disciplines. It was thought that social studies would enhance the promotion of unity and self-reliance, that is, the values which are critical to citizenship education. Following the recommendation of the 1994 Revised National Policy on Education (RNPE), Botswana's social studies curriculum was revised mainly to address the contemporary issues arising from globalization and the ever changing economic needs of the country. In 2008, the junior secondary social studies was further revised to keep pace with the dictates of the global economy. The revised three junior secondary social studies which was implemented in 2010, builds on the foundation provided by the Lower Primary Cultural Studies and Upper Primary Social Studies curriculum (http://www.moe.gov.bw). In 2008 social studies was only introduced as an optional 
subject in the senior secondary school curriculum. This after about fourteen years after the RNPE (1994) called for its introduction.

The MoESD conceptualizes social studies as the study of the relationship between human beings and the environment, past, present and future. It is an interdisciplinary subject that integrates content from an array of disciplines including history, political science, law, civics, geography and economics (http://www.moe.gov.bw). There is also the recognition of the need for social studies to address the benefits and challenges of living in a culturally diverse society. Social interactions have to be contextualized in space and time as well as having social, political, economic and environmental dimensions.

\section{The Method}

This study used document analysis and grounded theory as important complementary tools to understand the relationship between issues of gender and social studies education in Botswana's primary, junior and senior secondary schools in Botswana. This involved examining, interpreting, eliciting meaning, gaining understanding and developing empirical knowledge (Bowen 2009; Strauss \& Corbin 2008; Rapley 2007). I used grounded theory as the basis for critiquing (Goulding 2002) the primary, junior and senior secondary social studies curriculum. In addition I also drew on my prior knowledge and experience as a former secondary school social studies teacher, former social studies college lecturer and now a university lecturer teaching social studies to stimulate evaluation and comparison in the data. In generating the data for this study, I began by examining the official documents like the Lower Primary Cultural Studies Syllabus; the Upper Primary School Social Studies Syllabus; the Revised Junior Secondary School Social Studies Syllabus and the Senior Secondary Social Studies Syllabus.

\section{The Findings}

\subsection{Lower Primary Cultural Studies}

The Lower Primary School Cultural Studies syllabus as spelt out earlier is designed to meet the broad educational aims of Botswana's Ten Year Basic Education programme. The syllabus follows a thematic approach informed by the expanding horizon structure (http://www.moe.gov.bw/). That is, it emphasizes a concentric approach starting from the learners' experiences spiraling out to new experiences. For example, each succesive standard (i.e 1 to 4) raises the knowledge, skills and competency levels on a staircase format. The Cultural Studies syllabus deals with the interaction of human beings with their physical, social, economic and political environment. It also seeks to develop positive attitudes within learners to promote protection, preservation and sustainable use of the environment. More importantly, the Cultural Studies syllabus purports to infuse and integrate emerging issues such as HIV/AIDS and Enviromental Education (http://www.moe.gov.bw/). Yet, it appears that the intergration and infusion of gender issues remains the missing link on the Cultural Studies syllabus. In fact, there is no topic specifically devoted to the examinination of gender issues. However, one of the aims of the Lower Primary School Cultural Studies syllabus makes an indirect reference to gender issues: on completion of the four year programme learners should have developed awareness of human rights and responsibilities related to health, gender, law, violence, identity, civic and other social and moral issues. Even the specific and general objectives are silent on gender safe for only one: students should be able to identify themselves by name, gender and religion. Consistent with Hurren's (2002) observations regarding the extent to which the Social Studies Education effectively articualte gender equality and balance, Botswana's Cultural Studies syllabus also supports a hierarchical framework that privileges public (i.e. global issues) over private (i.e. local issues) spheres of life.

Throughout the four years, learners study topics generally revolving around the private sphere like: self, family, community, rights and responsibilities, authority structures at the local level, culture and physical environment and resources. Interestingly much of the content covered does not explicitly illuminate gender balance, equality and equity. Topics that could easily reflect gender issues are devoid of gender sensitivity. One would have expected the topic on children's rights and child abuse to explicitly highlight 'the girl child'. Similarly, the topic on human rights should have mentioned 'women's rights as human rights'. Similarly, the topic on equality in society does not mention gender equality and equity. The assumption is that the teacher will invariably make a clear distinction between the various forms of inequalities in society such as gender imbalance, ethnic inequality and income inequality. Furthermore, there is also evidence of implied gender bias in terms of the content of the Cultural Studies syllabus. For example, topics on the structure of authority in a family and ward, family roles, head of family and cultural values, beliefs and norms, are more likely to reinforce gender stereotypes particularly in a partriarchal 
society such as Botswana. Mannathoko's (1999) study also finds that this is not surprising given that Botswana's education system, just like in other southern and eastern African countries, is still gendered thus reproducing gender inequalities and injustices. In addition, gender stereotyping is still endemic such that some school textbooks still reinforce pictures and images that are stereotypical.

\subsection{Upper Primary Social Studies}

The Upper Primary Social Studies syllabus for standards 5 through to 7 builds on social studies skills of Lower Primary School Cultural Studies programme. Consistent with the expanding horizon curriculum structure, it uses broad thematic modules presented in sequencial and gradual built-up in-depth content coverage (http://www.moe.gov.bw/). Like the foundation programme, it claims to integrate and infuse emerging issues such as Environmental Education, Population and Family Life Education and HIV/AIDS. Not surprisingly, it fails to recognize gender as part and parcel of emerging issues but only makes a passing reference to gender issues. In fact, past studies have also revealed that Botswana's social studies education programme has failed to adequately articulate gender issues across all the levels of schooling. For example Mannathoko (1999) drawing on theories of oppression rightly observes that:

The concepts of modernity... gender, power and injustice featured prominently in the social studies lessons I observed across the board, be it a secondary school or primary level college. Time and again during lessons, teachers and lecturers never followed up issues of a gender nature which undergird the knowledge discussed during the lesson... the result was that women and girls' lives remained invisible throughout the lessons taught (p. 270).

For example, an in-depth examination of the Upper Primary Social Studies content reveals that there is no specific topic devoted to the study of gender issues. Most of the topics (which can easily host gender issues) like culture, family, agriculture and citizenship, are either devoid of gender (i.e. gender neutral) or presented in ways in which gender implications are not explicitly imbedded in the content. For example, a topic like agriculture does not reflect the significance of women in agricultural development and the fact that women are overburdened (Holmes and Slater 2008) in that they have to combine food production with household activities and yet their labour input is largely ignored and unpaid. Similarly, a topic like the village reflects gender bias content as it only highlights the roles and duties of chiefs (the majority of whom are males) but fails to articulate the role of women in village life.

Lastly, topics like the kgotla and village reflect the partriarchal and male-dominated nature of political institutions in promoting gender imbalance, inequality and discrimination. This kind of scenario is not only confined to the Botswana context. For example, the study by Davies (2008 cited in Arnot and Fennell 2008) carried out in Pakistan points out the view that "terrorism is associated with radicalized religious men is contradicted by the reality that there are many women suicide bombers and that terrorism goes beyond gender..." (p. 50). Tripp (2000) puts this differently when talking about the participation of women in extreme religious fundamentalist groups across the world. The key observation is that:

...women's bodies and morality have often become a battleground over the preservation of particularistic identities because of women's critical role in sustaining the future of a particular group through their proactive abilities, as socializing agents for children, and as transmitters of group values, traditions, and identity (, p.653).

Writing in the same article, Tripp (2000) observes that even in African countries characterized by armed conflicts, women have had to shoulder excessive responsibilities in maintaining the household in the absence of men. They have also been involved in efforts to find a solution to armed conflict by even going to the extent of maintaining stability and cross-line contacts through intermarriages and marriage ties that build bridges across ethnic groups. These crosscutting forms of mobilization go beyond the realization of harmony and cooperation as to reflect their daily experiences with political marginalization, exclusion and inequality.

\subsection{Three Year Junior Secondary Social Studies}

The three year Junior Secondary Social Studies programme builds on the foundation provided by Lower Primary School Cultural Studies and Upper Primary Social Studies programmes. It also does not mention gender issues with regard to infusion and integration of emerging issues. The three year Social Studies syllabus lists the infusion of emerging issues like Environmental Education, Information, Communication and Technology, HIV and AIDS, globalization and national issues such as road safety and citizen economic empowerment. Interestingly, the preamble of the syllabus observes that "there is a limit to the degree to which a syllabus document can infuse emerging issues, it is therefore imperative that the current and future issues should be infused at classroom level" (http://www.moe.gov/). The Structure of the Botswana's Three- Year Junior Secondary Social Studies Syllabus is also based on the expanding horizon curriculum approach (http://www.moe.gov.bw/). Modules and units such as 
social groupings, wider communities and project work on "who am I" are covered in forms 1 and 2. Complext modules and units on international relations and Botswana in the world are covered in forms 2 and 3.

In terms of content, the three year social studies syllabus has only one topic devoted to gender issues. More specifically, the focus is on the following: importance and promotion of gender equity, role and status of men and women, cultural practices that discriminate men and women, ways of empowering men and women and forms, causes and solutions to gender-based violence. It is evident that the preoccupation of the social studies curriculum design is gender neutrality - that is according equal coverage to men and women. Such an approach is superficial in that it does not start with the conceptualization and operationalization of gender issues. In addition, the syllabus does not make reference to the: evolution and the theoretical dimensions of feminist psychological and social research theories, the social construction of gender, socio-economic and political consequences of gender imbalance. The topics like the family, cultural heritage and citizenship are presented in ways that are devoid of gender dimension. Similarly, topics such as education and human resource development do not make reference to 'women and development' issues. It appears the general expectation is to require teachers to deliver gender change within schools yet as a society we hardly reflect on the impact of the gendered role of male and female teachers within the national school systems particularly in developing countries. What is known is that both male and female teachers tend to have negative attitudes to the education of the girl-child and women (Fuller, Hua and Snyder 1994; Manathoko 1999). However, it is important to go beyond the dictate of the sex role theory by examining the specific consequences of being taught by a male or female teacher. Arnot and Fennel (2008) is spot on in suggesting that the combined impact of pedagogic styles, teaching styles and attitudes of male and female teachers in developing countries need further scrutiny and interrogation.

\subsection{Senior Secondary Social Studies}

The Senior Secondary Social Studies curriculum builds on the Ten Year Basic Education programme. It also emphasizes the interdisciplinary nature of Social Studies curriculum whose main aims are to enhance: life long learning, world of work, critical thinking and citizenship education. The syllabus is organized into broad content areas called modules which are in turn sub-divided into topics. The content is further presented in the form of general and specific objectives. In contrast, to the Ten Year Social Studies Programme, the Senior Secondary Programme makes explicit reference to gender issues (http://www.moe.gov.bw/). For example, In the preamble of the senior secondary Social Studies Programme it is stated that "at this level, Social Studies should build in learners: cultural pride, tolerance and pragmatic attitudes towards critical issues such as gender, HIV/AIDS, globalization and the total commitment to the nation's development. Secondly, at the end of the two year programme learners should have: acquired knowledge, attitudes and practices that will enhance them to appreciate and respect equality of humankind irrespective of colour, race, ethnic group, gender, class or creed. Thirdly, learners should have acquired an understanding of emerging issues such as HIV/AIDS, global warming, globalization and gender relations.

Notwithstanding the rhetoric to embrace gender issues, the content of the senior secondary social studies syllabus suffers from the same inherent weaknesses outlined above. First, there is no specific module and topic on gender. Second, a large chunk of content is couched in either gender-biased or gender-neutral terminology. For example, the topic on the family rightly addresses the role of the family in terms of gender imbalance, sex education, teenage pregnacy and HIV/AIDS. However, there is no deliberate attempt to conceptualize and operationalize the concept gender. Nor is there any attempt to relate gender to: feminism, theories of gender and social construction of gender. This is rather startling at senior secondary level that invariably prepares students for tertiary level education. The topic on nation building reflects gender-biased content as it only mentions the role of dikgosi and kgotla. As observed earlier, these political institutions are symbols of the partriarchal nature of society which disempower and surbodinate women in general. For example, the role of women in nation building is not illuminated yet women are politically, socially and economically siginificant with respect to nation building (Chilisa and Ntseane 2010; Ridgeway and Correll 2004; Anneli 2000; Bailey et al. 2000; Welsh 1992; Lehman 1987). Yet, there is growing evidence (Moghadam 1994; Tripp 2000) from various case studies around the world which depict women as the embodiment of national identities. Ironically, the evaluation of the role of the different stakeholders in nation building like: the youth, individuals, government, ethnic groups and non-governmental organizations are singled-out leaving out the specific role played by women in nation building and development in general.

\section{Conclusion}

There is no doubt that since Botswana's independence in 1966, the state has initiated significant educational, social, political and economic changes allowing for improvement in the conditions of women as well as addressing gender 
inequalities and imbalances. Over the last four decades, both men and women benefited from the expansion and improvement of education. However, the impact of these in the reconstruction of gender in educational policy and practice has been rather limited. Botswana's education system is still gendered hence reproducing gender inequalities. This paper has for example, demonstrated that the various layers of social studies education straddling lower and upper primary, junior and senior secondary school do not adequately articulate gender issues. There still appears to be a large gap between policy intentions and actual practice regarding the mainstreaming of gender issues. Contrary to conventional understanding the state is not a neutral institution but rather an active one capable and willing to use educational policy and practice to initiate social change which have important implications for the subordination and exploitation of women. Attempts to address gender inequality in African schools in general and social studies education in particular need to go beyond focusing on barriers to access to education of girls, the high drop-out rates and low academic achievement of girls. There is need for concerted efforts for schools to factor in gender equality in the conceptualization of quality education and the school curriculum. The role of the state in using education policy and practice to create, adapt and reproduce patriarchy needs further interrogation.

\section{Recommendations}

The following recommendations were generated from the study:

1) The social studies curricula for Lower and Upper Primary, junior and senior secondary schools need to provide equal learning opportunities for girls and boys.

2) The content of the Lower Primary Cultural Studies syllabus needs to be reviewed with the view of reversing its hierarchical structure that privileges the public over the private sphere of life.

3) There is need to edit social studies textbooks across all the levels of schooling to remove stereotypical content, images and pictures which reinforce gender stereotyping.

4) Social studies teachers need to re-think their pedagogical and teaching styles and attitudes and ensure that these promote gender equality.

5) Curriculum development, textbooks, teaching and learning support materials need to take into account the pro-active role that women play in nation building.

\section{References}

Anneli, A. (2000). Introduction. In L. J. Parpart, P.Connelly \& E. V. Burriteau (Eds.). Theoretical perspectives on gender and development (pp. V-VIII). Ottawa: International Development Research Centre.

Apple, W. M. (1998). Teachers and Texts: a Political Economy of Class and Gender Relations in Education. New York: Routledge.

Arnot, M., \& Dillabough, J-A. (Eds.) (2000). Challenging democracy. International perspectives on gender, education and citizenship. London: Routledge Falmer.

Arnot, M., \& Fennell, S. (2008). Gendered education and national development: Critical perspectives and new research. Compare: A Journal of Comparative and International Education, 38, 515-523. http://dx.doi.org/10.1080/03057920802351275

Bailey, B., Leo-Rhynie, E., \& Morris, J. (2000). Why theory? In L. J. Parpart, P.Connelly \& E. V. Burriteau (Eds.). Theoretical perspectives on gender and development (pp. 1-22). Ottawa: International Development Research Centre.

Boikhutso, K. (1993). Vocationalization of the school curriculum in Botswana. MEd. Unpublished Dissertation, Bristol, University of Bristol.

Bowen, G. A. (2009). Document analysis as a qualitative research method. Qualitative Research Journal, 9, 27-40. http://dx.doi.org/10.3316/QRJ0902027

Chilisa, B., \& Ntseane, G. (2010). Resisting dominant discourses: implications of indigenous African feminist theory and methods for gender and education research. Gender and Education, 22(6), 617-632. http://dx.doi.org/10.1080/09540253.2010.519578

Connell, R. W. (2000). The men and the boys. Sydney: Allen \& Unwin Australia. 
Daatland, D. D. (Ed.) (2003). Education, human rights, and gender relations. Challenges for European schools today. Retrieved on the $26^{\text {th }} \quad$ May 2010 from http://www.learningmigration.com/files/report/1/LisbonReport03\%20kopi.pdf

Davies, L. (2008). Gender, education, extremism and society. Cited in M. Arnot and S. Fennell, 2006. Compare: A Journal of Comparative Education, 38, 611-625.

Deem, R. (1980). Introduction. Women, work and schooling: the relevance of schooling. In R. Deem (Ed.). Schooling for women's work. (pp. 1-12). Routledge \& Kegan Paul Ltd.

Dillabough, J-A., \& Arnot, M. (2000). Feminist political frameworks: new approaches to the study of gender, citizenship and education. In M. Arnot., \& J-A. Dillabough (Eds.). Challenging democracy. International perspectives on gender, education and citizenship. (pp. 21-41). London: Routledge Falmer.

Dillard, C. M. (2009). When the ground is black, the ground is fertile: exploring endarkened feminist epistemology and healing methodologies of the spirit. In Handbook of critical and indigenous methodologies, eds. M. Denzin., Y. Lincoln., \& L. Smith (pp. 227-291). Thousand Oakes, CA: Sage.

Eder, D., \& S. Parker, (1987). The Cultural Production and Reproduction of Gender: the effect of extracurricular activities on peer. Sociology of Education, 60, 200-213. http://www.jstor.org/stable/2112276

Fennell, S., \& M. Arnot. (2009). Decentralizing hegemonic gender theory: the implications for educational research. RECOUP Working Paper no. 21, Development Studies and Faculty of Education, University of Cambridge.

Friedman, L. (1995). The space factor in mathematics: gender difference. Review of Educational Research, 65, 22-50. http://dx.doi.org/10.3102/00346543065001022

Friedman, S. S. (1995). Beyond white and other: Relationality and narratives of race in feminist discourse. Signs, 21, 1-49. http://www.jstor.org/stable/3175121

Fuller, B., Hua, H., \& Snyder, C. W. (1994). When girls learn more than boys: The influence of time in school and pedagogy in Botswana. Comparative Education Review, 38(3), 347-376. http://www.jstor.org/stable/10.2307/1189066

Gordon, R. (1996). Legislation and educational policy in Zimbabwe: The state and the reproduction of patriarchy. Gender and Education, 8, 215-229. http://dx.doi.org/10.1080/09540259650038879

Goulding, C. (2002). Grounded theory. A practical guide for management, business and marketing researchers. London: Sage Publications Ltd.

Holmes, R., \& Slater, R. (2008). Measuring progress on gender and agriculture in the 1982 and 2008 World Development Report. Gender and Development, 16, 27-40. http://dx.doi.org/10.1080/13552070701876110

Howe, G. D., \& Marshall, D. D. (1999). Citizenship education, democracy and global shifts. Re-thinking Caribbean social studies. Kingston: UNESCO.

Hurren, W. (2002). Gender issues within the discursive spaces of social studies education. Canadian Social Studies, 36. Retrieved on $24^{\text {th }}$ May 2011 from http://www.edu.ualberta.ca

Lehman, E. C. (1987). Research on lay church members' attitudes toward women clergy: An assessment. Review of Religious Research, 28, 319-329. http://www.jstor.org/stable/3511637

Mama, A. (2003). Restore, reform but do not transform: the gender politics of higher education in Africa. Journal of Higher Education in Africa, 1, 101-125.

Mama, A. (2007). Critical connections: Feminist studies in African contexts. In A. Cornwall., E. Harrison., \& A. Whitehead (Eds.). Feminists in development: Contradictions, contestations and challenges (pp. 150-60). London: Zed Press.

Mannathoko, C. (1995). Botswana: politics of gender in teacher education curriculum and pedagogy. In P. T. M. Marope., \& D. W. Chapman (Eds.). A handbook of research on education: Teaching and teacher education in Botswana (p. 270). Gaborone: Lentswe La Lesedi.

Mannathoko, C. (1999). Theoretical perspectives on gender education: The case of eastern and southern Africa. International Review of Education, 45(5/6), 445-460.

Marira, C. (1991). Gender issues in Zimbabwe's two main English language textbooks in the primary schools. Zimbabwe Journal of Educational Research, 3, 108-124. 
Marshall, H., \& Arnot, M. (2007). Globalizing the school curriculum: Gender, EFA and global citizenship education. In S. Fennell., \& M. Arnot (Eds.). Gender education and equality in a global context: Conceptual frameworks and policy perspectives (pp. 165-80). London: Routledge.

Ministry of Education and Skills Development. n.d. The Lower Primary Cultural Studies Syllabus. Retrieved on the $20^{\text {th }}$ June 2010 from http://www.moe.gov.bw/

Ministry of Education and Skills Development. n.d. The Revised Juniour Secondary Social Studies Syllabus. Retrieved on the $20^{\text {th }}$ June 2010 from http://www.moe.gov.bw/

Ministry of Education and Skills Development. n.d. The Senior Secondary Social Studies Syllabus. Retrieved on the $20^{\text {th }}$ June 2010 from http://www.moe.gov.bw/

Ministry of Education and Skills Development. n.d. The Upper Primary School Social Studies Syllabus. Retrieved on the $20^{\text {th }}$ June 2010 from http://www.moe.gov.bw/

Mirza, S. M. (2004). Gender analysis of school curriculum and textbooks. Islamabad: UNESCO. Retrieved on the $20^{\text {th }} \quad$ June $2010 \quad$ from http://www.un.org.pk/unesco/documents/publications/education/Gender\%20Analysis\%20of\%20School\%20Co mmunity.

Moghadam, V. (1994). Introduction and overview. In V. Moghadam (Ed.). Gender and national identity. Women and politics in Muslim societies (pp. 1-17). Boulder: Westview.

Nyamu, I. C. (2000). How should human rights and development respond to cultural ligitimization of gender hierarchy in developing countries? Harvard International law Journal, 41, 381-400.

Nyati-Ramahobo, L. (1992). The girl-child in Botswana: educational constraints and prospects. Gaborone: UNICEF.

Rapley, T. (2007). Doing conversation, discourse and document analysis. London: Sage.

Reichert, M. C., \& Kuriloff, P. (2004). Boys' selves: identity and anxiety in the looking glass of school life. Teachers College Record, 106, 544-573.

Ridgeway, L. C., \& Slelley, J. C. (2004). Unpacking the gender system: A theoretical perpective on gender beliefs and social relations. Gender \& Society, 18, 510-531. http://dx.doi.org/10.1177/0891243204265269

Seboni, N. (1997). Botswana female youth: Perception of sexuality and risk taking behaviours. Mosenodi, Journal of the Botswana Educational Research Association, 5(1), 15-26.

Skelton, C., Francis, B., \& Smulyan, L. (2006). Introduction. In C. Skelton., B. Francis., \& L. Smulyan (Eds.) The sage handbook of gender and education. (pp. 1-17) London: Sage Publications.

Strauss, A., \& Corbin, J. (1998). Basics of qualitative research. Techniques and procedures for developing grounded theory. Los Angeles: Sage Publications.

Stromquist, N. P. (1990). Gender inequality in education: accounting for women's insubordination. British Journal of Sociology of Education, 11, 137-153. http://dx.doi.org/10.1080/042569900110202

Tetreault, M. K. T. (1987). Rethinking women, gender, and the social studies. Social Education, 5, 170- 178.

Thorne, B. (1993). Gender play: girls and boys in schools. Piscataway: Rutgers University Press.

Tripp, A. M. (2000). Rethinking difference: Comparative perspectives from Africa. Signs, 25(3), 649-675. http://www.jstor.org/stable/3175412

Tupper, J. (2002). The gendering of citizenship in social studies curriculum. Canadian Journal of Social Studies, 36(3). Retrieved on the $15^{\text {th }}$ June 2011 from www.quasar.ualberta.ca/css

United Nations Organization (1995). Platform of action and the Beijing declaration. New York: United Nations Department of Public Information.

Welsh, J. M. (1992). The construction of gender: Some insights from feminist psychology. Accounting, Auditing \& Accountability Journal, 5, 120-132.

Wolpe, A. M. (1998). Within school walls: the role of discipline, sexuality and the curriculum. London: Routledge. 